\title{
Supporting technology instruction through peer tutoring, discussion boards and electronic journals
}

\author{
Dan P. Dewey and Anne E. Cannon
}

Abstract

Dan P. Dewey (PhD, Carnegie Mellon University) is an Assistant Professor of Foreign Language Education at the University of Pittsburgh. His research focuses largely on two areas: advanced second language proficiency development (in particular through intensive immersion abroad and at home) and the use of technology in the language classroom.

Anne Cannon is currently a graduate student in the University of Pittsburgh School of Education where she is studying Foreign Language Education and completing a certificate in TESOL. She completed her Bachleor's degree in Political Science at Utah State University.

Given the diverse backgrounds and technical expertise that language teachers can possess, it is challenging for technology instructors to meet the needs of individuals during workshops or classes. In this study, we explored the effectiveness of three interventions implemented to help a technology instructor better meet the needs of individuals in his class: peer tutoring, asynchronous discussion board and electronic journal entries. Through the three interventions, the instructor's role changed from being the provider of solutions to every problem (firefighter) to being an available coach, able to focus his attention on matters that required it most. The instructor became well informed of individuals' challenges and frustrations through discussion board postings and journal entries. Learners regularly answered each others' questions and provided support and advice as they acted as peer tutors and as they exchange messages via the discussion board. A strong group dynamic developed as learners grew accustomed to assisting each other regularly. The instructor was able to adjust lessons according to needs perceived via journals and discussion board entries. He was also able to focus more attention on problems in class that required instructor attention (as opposed to questions readily answerable by peers). 
Supporting technology instruction through peer tutoring, discussion boards and electronic journals

Preparing foreign language teachers to use technology in the classroom frequently presents a difficult challenge to teacher educators. Language teachers come to classes and workshops equipped with a range of technological expertise-some having few computer skills and limited exposure to the software and hardware useful for teaching languages, and others possessing a range of computer skills useful for classroom instruction. Developing strategies for dealing with large individual differences and needs is key to successful teaching and learning in the educational technology classroom.

As Taylor (2003) has noted, students who have more experience using technology or feel confident about learning new technology usually prefer to learn independently by "playing around" with new tools with little interference from an instructor. Other students who favor learning through more traditional forms of instruction such as lecture, demonstration, guided hands-on experimentation and written guides may appreciate more intervention and structured guidance from the instructor. Many students may only feel comfortable if they have constant access to a technology expert to help them troubleshoot any problem that may arise as they attempt to familiarize themselves with the course-required technology. In short, there is a broad range of learning preferences as well as expertise. Accommodating these preferences presents additional challenges for an instructor.

This study focuses on the use of three instructional practices useful for helping educators deal with some of the challenges of teaching technology to foreign language teachers: student journaling, threaded discussion boards and peer tutoring. Each of these three practices was implemented in a technology course for language teachers in order to meet the needs of individuals in terms of knowledge development and learning styles. This paper is a qualitative case-based report of the effectiveness of these interventions in meeting the needs of individuals enrolled in this technology course.

Several studies on the use of e-mail and threaded discussions in distance programs for teacher education have focused on what students learn while using online communication tools. McFerrin (1999), for example, suggested that incidental, unplanned and unforeseen, learning occurred through an online technology in education course. Students reported increased patience and self-discipline, adaptability to non-traditional and isolated learning environments, and time management skills as incidental learning that took place through the online course. McFerrin (1999) also found that students reported growth in self-confidence and self- 
worth at the end of the online course. Another benefit cited was the development of an online community in which students offered and received assistance from one another, rather than solely from the instructor (Ohland et al., 1999).

Studying the nature of the interaction that took place among online learners (language teachers) who used asynchronous discussion forums, Pawan, Paulus, Yalcin, and Chang (2003) found that students do not always use online discussion forums as their instructors may have intended. Some of their participants frequently engaged in "serial monologues" in which they spoke at length about their own teaching experiences and opinions or engaged in small talk (Pawan et al., 2003). These participants did not link their own comments to the comments of other discussion board participants by answering questions or responding to discussion starters of others.

Recent studies on the use of asynchronous and synchronous communication within traditional on-campus teacher education courses suggest that electronic communication tools allow students and instructors to overcome obstacles of time and distance even when face-to-face meetings occur regularly (Estes et al. 1999; Justice 1999; Khan 2005; Levin 2000; McMullin, Goldbaum, Wolffe, and Sattler, 1998; Nicholson and Bond 2003). Khan (2005) showed that students did not have to "bid" for the instructor's attention as much within the classroom because they could continue to make comments, ask questions and discuss material with the instructor and their peers on the discussion boards or by e-mail. Nicholson and Bond (2003), Estes (1999) and McMullin et. al. (1998) demonstrated that classroom discussion time was extended beyond the class period through discussion boards and e-mail journals. These tools facilitated ongoing discussions between students and their peers and students and their instructor.

Studies that have examined the content and nature of messages written for course-required e-mail journals and online discussion forums (Dutt-Doner and Powers 2000; Levin 2000; Nicholson and Bond 2003; Pawan et al. 2003) have reported that students used asynchronous discussion boards for reflecting on their own professional development, exchanging ideas about teaching and offering support. Levin studied e-mail messages exchanged among students and between students and the instructor, and messages posted to an online discussion board, and found that "peer-to-group" online discussions through online forums "appeared to foster reflection more than the other forms of one-to-one electronic communication studied" (2000, 151-152).

The third practice to be explored in this article is peer-to-peer tutoring. Teachers involved in a five-year study of 32 technology- 
intensive elementary and secondary classrooms observed that peer tutoring and the use of student experts freed them from the role of primary instructor of basic technology skills; allowed for more personalized, one-on-one instruction; brought about positive change in students' academic performance and "senses of self-efficacy;" (Ringstaff, Sandholtz and Dwyer 1991, 12) and lead to their greater awareness of students' capability and talent.

This paper demonstrates the potential of e-mail journals, asynchronous electronic discussion boards and peer tutoring to increase an instructor's ability to meet the needs of individuals enrolled in a course on using technology in the foreign language classroom. Research indicates that as learners participate in these activities, they are likely to develop greater confidence, engage in more collaborative learning, and provide greater support and advice for each other. These results can build an environment where learners are more able to meet their own needs and to have some of their needs met through their peers. It follows that as this occurs, an instructor can then better act as a coach on the sidelines, to guide learners in their individual and collaborative efforts, and to provide focused support where his or her expertise is most needed. The report that follows demonstrates how this process can occur in the technology classroom.

The Setting

Students in a course on technology in the foreign language classroom were given three assignments designed to inform the instructor of their progress, to facilitate the meeting of individual needs, and to create a stronger group dynamic: e-mail journals, asynchronous electronic discussion boards and peer tutoring. What follows is a description of this course and learners and of the three assignments, which will hereafter collectively be referred to as the three target assignments.

The fifteen-week three-credit course, "Technology in Foreign Language Education," met once a week for three hours. The instructor designed the course to teach teachers of foreign languages a set of skills that would allow them to use technology in their classrooms. Although the course emphasized using technology in pedagogically sound ways (assignments were evaluated for pedagogical value as well as technical merits), the focus was not on materials or lesson plan design. These practices were taught extensively in other teaching methods classes, where assignments were often fulfilled using technology. The primary focus of the course was on the acquisition of a set of technical skills helpful for implementing technology in the classroom.

This paper reports on the learning of a very diverse group of 54 students at the University of Pittsburgh: 24 in one class and 30 in another. These learners included student teachers, master's and doctoral 


\section{Feature}

students. Forty of the participants were pre-service teacher candidates and the remainder were practicing teachers participating for professional development purposes. The technological expertise of the participants varied greatly. Students included both highly capable and less capable individuals: a former computer programmer and a retired banking industry systems analyst on the highly skilled end, and self-proclaimed "technology idiots," who struggled even to check their e-mail and send and receive attachments at the other end. In short, wide-ranging abilities and needs of the individuals enrolled in the course presented significant challenges for the instructor, who wanted to provide meaningful and useful instruction for all individuals.

Students in the course were required to complete small weekly assignments involving skills such as using Blackboard, creating web tools (links, tables, frames, forms, etc.), downloading, editing and manipulating graphics, editing digital video and audio, creating HotPotatoes activities and PowerPoint presentations and more. They also wrote evaluations of commercial software and read several short articles on technology in the classroom. For a final course project, learners were required to integrate at least three skills taught in the technology course to create a series of activities for use in their classrooms. They were also to demonstrate an understanding of how to effectively implement these activities through lesson plans and explanations of their teaching contexts and the theory and goals driving their projects.

To increase awareness of students' needs and to provide additional means of support to the learners, the instructor also required that students complete weekly e-mail journals or discussion board postings (worth $10 \%$ of their course grade) and that they act as "expert for the week" (peer tutor) during the semester (also worth $10 \%$ of course grade). To accommodate those less comfortable with the public discussion board forum, the instructor gave students the option of either writing journal entries and sending them directly to the instructor or posting a message to the threaded discussion board using Blackboard (Blackboard, 2005).

The instructor designed the three target assignments to help him better meet the needs of individuals enrolled in the course. He felt that by paying large amounts of attention to the needs of some individuals, he may have been overlooking the needs of others. The instructor thought that having learners write journal entries after each class would give him a better sense of each individual's understanding and progress. He asked the learners to consider the following questions as they prepared their entries for e-mail submission each week: 
1) How well were you able to use the tools taught in class this week?

2)How well did the instruction facilitate learning?

3)What obstacles did you encounter during class this week?

4) How difficult was it to complete the homework assignments for the week?

5) What specific aspects of the homework assignments were most difficult?

6) How are you feeling about your progress in this course this week?

7)If you could change anything about the course this week, what would you change?

8) How well were the instructor and/or the weekly experts able to help you this week?

9)In what ways were the instructor and those assisting him able to help?

Students were not necessarily required to answer all of the journal questions, but the instructor wanted to encourage them to consider these types of questions as they formulated their responses. He gave journal writers full credit if they addressed these questions or focused on related issues in a paragraph or more of text. Single sentences were not accepted and partial credit was not given.

The following prompt guided discussion board posts and appeared each time students logged into the discussion board:

The purpose of this discussion board is to allow each of you to share thoughts, concerns and questions you may have regarding the skills taught in each class. Each week please make at least one posting. This posting may be a thought, a question, or an answer to someone else's post, but I encourage you to each post both your own thoughts on class and a response to others' questions or comments each week where possible. While I do not require your posting to be of any specific length, I ask that you do your best to make each week's posting a meaningful one. Please respect others as you make your comments. Criticism of others will not be accepted, given that one aim of this discussion board is to provide support for all who post and read here.

Students were given full credit for discussion board postings each week if they made a post indicating that they gave thought to the material covered in class or that they read and gave a meaningful response to others' comments. 
Each student was required to act as expert for the week at least twice during the semester. Each week, two or three students met with the instructor between classes to learn how to use the tool or tools that would be covered in the upcoming class. Students spent between 10 and 30 minutes with the instructor learning these skills and then practiced on their own before the next class in order to become competent enough to teach their fellow learners. The instructor encouraged students to become experts in technologies they were not familiar with so that they were forced to learn well a set of new skills, but this was not a requirement. As a result of this, those participants already familiar with the technology, but not acting as experts for the week, often functioned as additional experts if needed. Experts were given full credit for participation if they met with the instructor during the week and if they stood and circulated to offer help during the class period. Partial credit was not given.

\section{Results}

\section{Journal Entries}

Evaluation of the success of the three target assignments involved several forms of evidence. First, two of the assignments, journal entries and discussion board postings, served as rich sources of information themselves. Second, the authors used anonymous course evaluations submitted by students at the end of the semester and read by the instructor well after grades were submitted. Third, the instructor conducted informal focus groups following each semester. Comments from these focus groups provided useful feedback regarding each of these methods. Finally, the authors analyzed two forms of evidence written by the instructor: instructor's responses to e-mail journal entries and discussion board postings, and the instructor's end of semester/class log. Journal entries and discussion board postings were categorized in an interactive manner, with categories being created and later modifications driven by patterns in the data, following methodologies for coding qualitative data outlined in Miles and Huberman (1994) and Charmaz (2005).

The impact of the journal entries, the discussion board and the expert for the week program will be presented with an emphasis on how these interventions accommodated individual differences and allowed the instructor to better meet the needs of his students.

Results from the journal entry analysis are summarized in Table 1. The table lists the eight most common comment types in order of frequency (most to least). Less frequent types (all occurring less than five times each) are not included in the table. 
Dewey and Cannon

\begin{tabular}{|c|c|c|c|}
\hline Frequency & Category & Description & Example \\
\hline 80 & Frustration & $\begin{array}{l}\text { Students express } \\
\text { frustrations related to } \\
\text { the class. }\end{array}$ & $\begin{array}{l}\text { "I have no clue what is going on. ... } \\
\text { At this point I just feel like this proj- } \\
\text { ect is never going to start moving } \\
\text { again. Sorry for such a negative jour- } \\
\text { nal this week. That's why I kept trying } \\
\text { before writing, but I have to give up } \\
\text { right now. I'm just SO frustrated." }\end{array}$ \\
\hline 61 & Difficulty & $\begin{array}{l}\text { Students comment } \\
\text { on the difficulty of } \\
\text { specific tasks or } \\
\text { projects. }\end{array}$ & $\begin{array}{l}\text { "This is one of the hardest things } \\
\text { we've learned how to do so far." }\end{array}$ \\
\hline 48 & $\begin{array}{l}\text { Technology } \\
\text { Observation }\end{array}$ & $\begin{array}{l}\text { Students make a gen- } \\
\text { eral comment about } \\
\text { the nature or capa- } \\
\text { bilities of technology } \\
\text { tools taught in class. }\end{array}$ & $\begin{array}{l}\text { "I like how you can create tables so } \\
\text { easily in GoLive. I wonder if I can } \\
\text { create tables within tables with it." }\end{array}$ \\
\hline 39 & Goals & $\begin{array}{l}\text { Students specify } \\
\text { goals. }\end{array}$ & $\begin{array}{l}\text { "My goal for the web site is to work } \\
\text { continuously for the following week to } \\
\text { learn the new skills I need to finish the } \\
\text { section I've been having trouble with." }\end{array}$ \\
\hline 31 & $\begin{array}{l}\text { Technology } \\
\text { Accomplishment }\end{array}$ & $\begin{array}{l}\text { Students describe } \\
\text { something that they } \\
\text { accomplished using } \\
\text { technology during } \\
\text { the week. }\end{array}$ & $\begin{array}{l}\text { "I created three mail-to forms to use } \\
\text { in activities for my class this week." }\end{array}$ \\
\hline 24 & How To & $\begin{array}{l}\text { Students ask questions } \\
\text { regarding how to } \\
\text { perform a specific } \\
\text { operation on the } \\
\text { computer. }\end{array}$ & $\begin{array}{l}\text { "Can you remind me how to make a } \\
\text { picture smaller once you get it off the } \\
\text { Internet?" }\end{array}$ \\
\hline 22 & Ability & $\begin{array}{l}\text { Students comment } \\
\text { on their own ability } \\
\text { or inability to do a } \\
\text { given task }\end{array}$ & $\begin{array}{l}\text { "I didn't realize in class how confident } \\
\text { I felt, but later on when I reflected I } \\
\text { realized that I know a lot more than I } \\
\text { thought. I'm able to do everything we } \\
\text { went over, and it's a good feeling." }\end{array}$ \\
\hline 18 & $\begin{array}{l}\text { Comment on } \\
\text { Journal } \\
\text { Writing }\end{array}$ & $\begin{array}{l}\text { Students talk about the } \\
\text { task of writing weekly } \\
\text { journal entries. }\end{array}$ & $\begin{array}{l}\text { "I'm not sure what to write this week. } \\
\text { It's sometimes hard to write these." }\end{array}$ \\
\hline
\end{tabular}

Table 1. Journal entry category descriptions and frequencies (listed in order of frequency). 
Journal entries indicated regular active reflection by individual writers. Learners addressed their own abilities, frustrations or apprehensions, actions and goals. In a focus group regarding journal writing, one learner noted, "it gave me a sounding board-sort of a place I could go to express my frustrations or tell my successes, and in some ways made me accountable.... Some weeks I could tell someone what I was going to do and then felt guilty if I didn't." This comment largely summarizes the main roles journals played for learners.

Having a better understanding of students' abilities, frustrations or apprehensions, actions and goals through the journals, the instructor not only was able to respond to and try to meet individuals' needs based on e-mail correspondence, but also to assess and answer many of the needs of the class as a whole, as depicted in multiple journal entries. One week several students expressed frustration over upcoming workload in their journal entries. The instructor was able to respond to these frustrations by reducing several specific demands and negotiating a more manageable workload in class with students. Another week he was able to re-teach a skill that journal entries indicated was not acquired well during a previous class. An added benefit was that students felt, "our concerns were being heard, even if [our instructor] didn't always feed us the specific answer we wanted, and sometimes [our instructor would] talk about problems I brought up in my journal, but even if [he] didn't, it felt good that [he was] always listening."

Students occasionally included specific "how-to" questions in their journal entries. Answering these questions outside of class reduced the amount of time in class required for answering individuals' questions. When more than one learner brought up a similar question or concern, the instructor was able to address these questions well in class, having prepared in advance to do so.

In short, journal entries provided the instructor with an understanding of the progress and attitudes of each individual. This understanding allowed him to follow up on journal entries with one-on-one e-mail communication and face-to-face support where necessary outside of class. He was able to provide support and encouragement and to adjust instruction according to students' needs as perceived through reading journal entries.

Discussion Board

Discussion board entry analysis results are displayed in Table 2. Only the most frequent categories (thirty or more instances) are displayed in the table. Six of the eight most frequent comment types involve sharing ideas, help, or support with other students or seeking this help and support. This help and support is evidence of a strong group dynamic that was present for the group. Several postings highlight this dynamic: 
Example 1: "I think one of the greatest benefits of technology is that it facilitates the creation of a cohort. Even though we only see each other for a few hours on Thursday nights, we're able to chat on the discussion board and share ideas."

Example 2: "[It] is not very often that a group of people can work together and help each other the way that we did. Many people offering support through phone calls, e-mails, discussion board advice, and their time, to help each member through what seemed to be huge problems."

Example 3: "Discussion [boards] are great for group dynamics, as I can work with students that I don't usually see outside of class. I feel I have support, and many times it is comforting to see you all have the same questions and concerns as I do." 


\begin{tabular}{|c|c|c|c|}
\hline Frequency & Category & Description & Example \\
\hline 140 & $\begin{array}{l}\text { Responding } \\
\text { to Requests }\end{array}$ & $\begin{array}{l}\text { Students respond to } \\
\text { requests for help }\end{array}$ & \multirow{5}{*}{$\begin{array}{l}\text { Student A: "Help! I can't get my stupid } \\
\text { form to work!" } \\
\text { Student B: "Why don't you post your } \\
\text { form and we can see what } \\
\text { we can do to help." } \\
\text { Student A: "Here's my form. I can't for } \\
\text { the life of me figure out } \\
\text { what I'm doing wrong!" } \\
\text { Student B: "I've got the form working for } \\
\text { your page. I'll tweak it a bit } \\
\text { more in the coming days. }\end{array}$} \\
\hline & & . & \\
\hline \multirow{3}{*}{127} & \multirow{3}{*}{$\begin{array}{l}\text { Requesting } \\
\text { Help }\end{array}$} & \multirow{3}{*}{$\begin{array}{l}\text { Students ask for help } \\
\text { from their peers. }\end{array}$} & \\
\hline & & & \\
\hline & & & \\
\hline 69 & $\begin{array}{l}\text { Expressing } \\
\text { Sympathy or } \\
\text { Support }\end{array}$ & $\begin{array}{l}\text { Students express } \\
\text { sympathy for other } \\
\text { students when they } \\
\text { express frustration or } \\
\text { discuss problems. }\end{array}$ & $\begin{array}{l}\text { "I'm so sorry to hear about your drive } \\
\text { problems! I had the same thing happen } \\
\text { to me last month. Makes you want to } \\
\text { pull your hair out, doesn't it :-( ." }\end{array}$ \\
\hline 64 & Offering Help & $\begin{array}{l}\text { Students offer to help } \\
\text { out without being } \\
\text { asked by other } \\
\text { students. Usually } \\
\text { this involves offering } \\
\text { expertise in a } \\
\text { specific area. }\end{array}$ & $\begin{array}{l}\text { "If anyone has any questions on } \\
\text { how to use courseweb please let } \\
\text { me know" ... "I'm good with today's } \\
\text { technology, so, once again, if anyone } \\
\text { has any questions, please feel free } \\
\text { to contact me via e-mail ... or } \\
\text { telephone...." }\end{array}$ \\
\hline 48 & $\begin{array}{l}\text { Commenting } \\
\text { on Class }\end{array}$ & $\begin{array}{l}\text { Students comment } \\
\text { on the nature of a } \\
\text { specific class or the } \\
\text { class in general. }\end{array}$ & $\begin{array}{l}\text { "This week's class wasn't as } \\
\text { challenging as last week's." }\end{array}$ \\
\hline 45 & $\begin{array}{l}\text { Sharing New } \\
\text { Ideas }\end{array}$ & $\begin{array}{l}\text { Students share ideas } \\
\text { for using technology } \\
\text { in their classrooms- } \\
\text { ideas that were not } \\
\text { presented by the } \\
\text { instructor or others in } \\
\text { class. }\end{array}$ & $\begin{array}{l}\text { "Here's another idea l've been throwing } \\
\text { around for my own classes and it } \\
\text { might work for your sites." The student } \\
\text { then goes on to give an extensive } \\
\text { description of publishing a Spanish } \\
\text { newsletter on her web site and using it } \\
\text { with a class she is teaching. }\end{array}$ \\
\hline 41 & $\begin{array}{l}\text { Describing } \\
\text { Independent } \\
\text { Learning } \\
\text { Experience }\end{array}$ & $\begin{array}{l}\text { Students write about } \\
\text { learning new skills (not } \\
\text { taught in class) on their } \\
\text { own as they experi- } \\
\text { ment with technology } \\
\text { outside of class. }\end{array}$ & $\begin{array}{l}\text { "Once I got down how to make } \\
\text { Quicktime movies, I played with things } \\
\text { on my own and figured out how to } \\
\text { add these movies to my web pages. } \\
\text { Then I found a web site provider to } \\
\text { store my pages and movies on, since } \\
\text { they're too big for our school space." }\end{array}$ \\
\hline 31 & $\begin{array}{l}\text { Agreeing } \\
\text { with Others }\end{array}$ & $\begin{array}{l}\text { Students agree with } \\
\text { points others express } \\
\text { on the discussion } \\
\text { board. }\end{array}$ & "I agree that this week's class was easier." \\
\hline
\end{tabular}

Table 2. Discussion board category descriptions and frequencies (most frequent to least). 


\section{Peer Tutoring/Expert for the Week}

Peer tutoring was evaluated by looking for comments about the experience in students' journals and discussion board postings and by reviewing post-study focus group comments, course evaluations and instructor notes. The most prevalent theme in all of these items was a transformation of students from less confident to more confident through acting as expert for the week. Several comments illustrate the development of confidence by individuals participating as experts. Regarding the use of Adobe GoLive for tasks such as creating tables, one student expert for the week wrote, "I was really scare [sic] at first but it is actually pretty easy to use and you can do pretty cool stuff with it. I am really excited about it." Another student chose to be an expert for the week for a class on digital video editing because "I tried to find something I thought would be the most challenging and that maybe I wouldn't be able to do." She later commented on the discussion board on her ability to use Apple's iMovie to edit digital video footage. "I am an expert for next week, and what [our instructor] showed us after class was amazing. I think we will all feel like real movie editors (as we will be!) after using iMovie because the effects and features are incredible. I never thought that editing a clip would be so easy and look so professional at the same time. Believe me, you all will love this program." The learner later mentioned to the instructor in class that she never thought she would be able to show others how to become "little film makers." Her vision of her ability to edit digital video changed from viewing the task as nearly impossible to describing herself as a "real movie editor."

As several discussion board comments illustrate, students developed a better understanding than usual of each of the tools as they acted as expert for the week. "I liked class tonight because we all had a lot of fun playing around with everything. I was also expert of the week so it was nice to actually be able to understand what was going on. . .. Normally it takes me about half the class to start picking things up,..." (Student 43). "I was the expert for the week, so it was nice to be able to play with everything and ... understand what was going on." (Student 3 ). Although students who were not experts normally left with sufficient understanding to use the tools taught in class each week, they were much more confident and capable when they had acted as experts.

Students came to realize that they were capable of learning much on their own as well: "Being the Expert for the Week made me realize that if I practice, I can even teach this stuff myself." (Journal Entry 7, Student 45). An interview comment showed a willingness to be more independent in learning: "Yeah, I found myself wanting to be the Expert for the Week more often.... I tried on [sic] two or three other things I thought would be kind of interesting to learn ahead a bit-or at least to do some reading or playing...." 
Expert for the week also promoted group cooperation and collaboration. Postings such as the following, by the expert for the week on the HotPotatoes program, were typical (16 similar comments were made by experts). "Please, if you have any questions about hotpotatoes post them up on the board and I will try to help as much as possible. I check this quite often." One student's course evaluation comment also suggests the influence of expert for the week on group dynamic: "I think having Experts each week forced us to rely more on each other. I suggest [the instructor] continue this program, given how much it forced us to help each other more and rely on the instructor less."

Evidence of individuals learning from weekly experts was also plentiful. "Expert for the Week was a great way for us to pitch in and help each other. I was ... skeptical because I didn't think I could learn much from them, but now I know it's possible to learn and teach quite a bit from all of them" (Interview, Student 41). "I was very confused at first, but then when Robert and Thomas showed me how to play around on it and get my movie to work in it, it was great!" (Discussion Board Post, Student 11, names changed to pseudonyms). Comments indicating learning from the experts appeared 21 times on the discussion boards-either in the form of a direct response to a question on the discussion board by an expert or in the form of a learner reporting having received help outside of the discussion board venue from an expert.

\section{Discussion}

The purpose of this paper is to highlight the potential of e-mail journals, asynchronous electronic discussion boards and peer tutoring to increase an instructor's ability to meet the needs of individuals enrolled in a course on using technology in the foreign language classroom. Given that the results presented here are anecdotal, it is impossible to make generalizations based on the data presented. However, the analyses did highlight some of the apparent benefits to students and teacher of these three target assignments in this particular situation.

Several patterns emerged from the data. Each of the three interventions appears to have contributed to noteworthy growth in self-confidence in terms of technology use of the individuals enrolled in the class. Journal entries and discussion board postings showed individuals moving from less to more confident over time. As students experienced being expert for the week, they realized that they were more capable than they initially thought. Like Ringstaff et al's (1991) study, this study indicated that even learners who were considered less capable initially (by themselves or the instructor) were able to participate in and draw confidence from being expert for the week. These same individuals reported gaining strength and confidence from the encouragement of fellow students through the discussion board and from their instructor through replies to journal 
entries. Ediger (2001) and McIntosh (1991) also indicate the value of journal writing in terms of increased self-efficacy in science and math problem classrooms. As several students noted in journals and interviews, the level of attention that each individual received through the journal entries, discussion board and peer tutoring contributed to the development of greater self-confidence. This degree of attention would not have been possible if the instructor had relied solely on office hours and in-class interactions.

Prior to the implementation of journals, the discussion board and peer tutoring, the course instructor was frequently frustrated by the challenge of listening to and dealing with the questions and struggles of individuals during each class, in particular when enrollment numbers were high. He would occasionally be surprised when a student would drop the course out of frustration or when he would hear of a student's concerns through other students or instructors. In short, it was difficult for him to determine and meet the needs of each individual during the weekly class periods. The three interventions allowed him to hear students' voices outside of class often and to focus classroom time on individuals particularly in need of his help. Students described this change as "having a voice in the class." Students who wrote journal entries felt that the instructor listened to and responded to their concerns and questions related to the course itself and the technology covered in class. Those who wrote discussion board postings felt that their concerns and questions were regularly addressed by classmates and the instructor. Finally, as one student noted, "Being the expert for the week made me feel like we had some control of the classroom. If things went well, we were to blame .... If they went poorly, we had some blame to take as well." In short, the instructor was better able to assess and meet individuals' needs by hearing their voices and allowing them to participate in classroom instruction as experts.

Prior to the three interventions, the instructor was regularly overwhelmed outside of class with requests for help. Students frequently had technical questions, but would also approach the instructor to express general feelings of frustration and lack of confidence. Journals, discussion board postings and peer tutoring created a group dynamic that led to individuals seeking support (both techni$\mathrm{cal}$ and moral) on a regular basis from their peers. Although some of the group dynamic present in the classroom could be attributed to the fact that many students took other classes together, the data indicate that the discussion board and peer tutoring were major contributors to this dynamic. Discussion board postings contained many examples of peer-to-peer support. As one student put it, the instructor "didn't even have to help us. We helped ourselves." Students were so fast to answer each other's questions on the discussion board that 
the instructor rarely had a chance to provide answers via this forum. Although some studies of asynchronous discussion boards (e.g., Pawan et al., 2003; Pena-Shaff and Nichols, 2004) have shown that learners can engage in monologues, seldom responding to each others' comments, many others (e.g., Arnold and Ducate, 2006; McFerrin, 1999; Bonk and King, 1998; Kamhi-Stein, 2000; Mitchell, 2003) have indicated that learners can respond thoughtfully to each others' postings and that a strong group dynamic can be present in the discussion board forum, in particular if discussion board instructions are worded in a manner that encourages responding to peer postings. Similarly, studies of peer tutoring in other disciplines (e.g., Ringstaff et al, 1991) have revealed that group bonding is a common result from peer-to-peer tutoring. The group bonding that occurred in this study provided an atmosphere where the instructor was a coach on the sidelines, providing guidance only where needed. Through the expert for the week program, he was assisted by other capable assistant coaches who freed up his attention to allow him to have a better view of the larger picture and to spot individuals needing one-on-one attention most.

In conclusion, the three interventions described here, journal writing, discussion boards and peer tutoring, allowed the instructor to change his role radically. Prior to implementing these three interventions, he often felt like a single firefighter trying to exterminate small and frequent fires spread throughout an entire city. While he was able to maintain some degree of control most days, there were others when the fires grew too large or when his ability to go from one emergency to the next was entirely inadequate. The move from single firefighter to sideline head coach led to an increased view of the scene and an ability to focus on specific problems requiring his expertise. Assisted by other coaches (experts for the week) and team members (classmates providing assistance through the discussion board and in-class help), and informed by reports (journals) from individual team members feeling the need for one-on-one assistance, he was able to direct the team through careful observation and leadership and occasional intervention. 


\section{References}

Arnold, N., and Ducate, L. (2006). Future foreign language teachers' social and cognitive collaboration in an online environment. Language Learning and Technology, 10(1), 42-66.

Blackboard. Web Application, version 6.0. Washington DC: Blackboard, Inc., 2005.

Bonk, C. and King, K. (1998). Computer conferencing and collaborative writing tools: Starting a dialogue about student dialogue. In C. Bonk and K. King (Eds.), Electronic collaborators: Learnercentered technologies for literacy, apprenticeship, and discourse (pp. 3-24). Mahwah, NJ: Lawrence Erlbaum Associates, Publishers.

Charmaz, K. (2000). Grounded theory: Objectivist and constructionist methods. In N. K. Denzin and Y.S. Lincoln (Eds.), Handbook of qualitative research. (2nd ed., pp. 509-535). Thousand Oaks, CA: Sage.

Dutt-Doner, K., and Powers, S. 2000. The use of electronic communication to develop alternative avenues for classroom discussion. Journal of Technology and Teacher Education 8(2): 153-172.

Ediger, M. 2001. Student journal writing in science. ERIC Document Reproduction Services Number ED 448462.

Estes, T., Bronack, S., and Schoeny, Z. February and March 1999. Creating optimized learning environments: A course using interactive web elements. Paper presented at the Society for Information Technology \& Teacher Education International Conference, San Antonio, TX.

Justice, M., and Expinoza, S. February and March 1999. Online communication-Building learning communities. Paper presented at the Society for Information Technology \& Teacher Education International Conference, San Antonio, TX.

Khan, S. 2005. Listservs in the college science classroom: Evaluating participation and "richness" in computer-mediated discourse. Journal of Technology and Teacher Education 13(2): 325-351.

Levin, B. 2000. Analysis of the content and purpose of four different kinds of electronic communications among preservice teachers. Journal of Research on Computing in Education 32(1): 139-156.

McFerrin, K. M. 1999. Incidental learning in a higher education asynchronous online distance education course. SITE 10(1999): Society for Information Technology and Teacher Education International Conference Proceedings. Charlottesville, VA: Association for the Advancement of Computing in Education. (ERIC Document Reproduction Services Number ED 432 288). 
McIntosh, M. 1991. No time for writing in your class? Mathematics Teacher 84(6): 423-433.

McMullin, D., Goldbaum, H., Wolffe, R., \& Sattler, J. February 1998. Using asynchronous learning teachnology to make the connections among faculty, students and teachers. Paper presented at the Annual Meeting of the American Association of Colleges for Teacher Education, New Orleans, LA.

Miles, M. B., and Huberman, A.M. (1994). Qualitative data analysis: A sourcebook for new methods (2nd ed.). Thousand Oaks, CA: Sage.

Nicholson, S., and N. Bond. 2003. Collaborative reflection and professional community building: An analysis of preservice teachers' use of an electronic discussion board. Journal of Technology and Teacher education. 11(2): 259-279.

Ohland, B., S. Andrews, C. Yu, A. Jannasch-Pennell, and S. DiGangi. April 1999. Impact of asynchronous and synchronous internetbased communications on collaboration and performance among K-12 teachers. Paper presented at the Annual Meeting of the American Educational Research Association, Montreal, Quebec, Canada.

Pawan, F., T. Paulus, Y. Senom, and C. Chang. 2003 Online learning: Patterns of engagement and interaction among in-service teachers. Language Learning and Technology, 7(3), 119-140.

Penna-Shaff, J. B., and Nichols, C. (2004). Analyzing student interactions and meaning construction in computer bulletin board discussions. Computers and Education, 42(3), 243-265.

Ringstaff, C., J. H. Sandholtz, and D. C. Dwyer. 1991. Trading places: When teachers utilize student expertise in technology-intensive classrooms. (Research report number 15). Apple Computer, Inc., Cuptertino, CA., (Retrieved October 5, 2005)

Taylor, L. 2003. ICT skills learning strategies and histories of trainee teachers. Journal of Computer Assisted Learning. 19 129-140. 